\title{
RED BIOTECHNOLOGY: A HEALTHY WORLD
}

\author{
Elsayed I.G, Ivantsova M.N. \\ Institute of Chemical Engineering, Ural Federal University, Yekaterinburg, Russia \\ Email: Israa_gaber@yahoo.com
}

Red, is not only a color; it's a branch of biotechnology which helps mankind fight either infectious or inherited diseases. We are already in the $21^{\text {st }}$ century, and yet we still witness multiple diseases. Some of them are even endemic, which makes it worse.

Red Biotechnology has been used since man discovered MOs and distinguished infectious agents. Since then we have been trying to find cures for different disease, biopharmaceuticals were being used effectively since the discovery of Penicillin by Alexander Fleming in 1928, and recombinant human insulin (rHI, trade name Humulin), which was developed by Genentech and marketed by Eli Lily in 1982.

Since then, MOs have been evolving and we are running out of anti-biotics, as they grow resistant to it a day after day. Biotechnology is developing as well, but obviously not as fast. Techniques on its own is very expensive; trials take a long time as well. The question is, would biotechnology be able to meet the needs of a biological system? Would we be able some day to fight back MOs with their weapon?

Here, we'll try to review some of the latest techniques in the field, which makes us understand how far we've come, and realize our capabilities and challenges on top.

Transgenics is considered a solution for many dilemmas we have nowadays. We believe it's a promising solution, nothing is much better than using a bioreactor which could be an animal, plant or even a bacterium to produce a medicine which is desperately needed.

Nanomedicine ranges from the medical applications of nanomaterials and biological devices, to nanoelectronic biosensors, and even possible future applications of molecular nanotechnology such as biological machines. Current problems for nanomedicine involve understanding the issues related to toxicity and environmental impact of nanoscale materials.

3D BioPrinting, the process of using bioink composed of tissue or human cells, has come a long way over the last decade. The goal of developing functioning whole organs, such as kidneys, livers or hearts, is becoming more and more of a reality.

Host Cell Proteins (HCPs) are process-related impurities, expressed by the host cell used for production of biopharmaceutical proteins. During the purification process, the majority of HCPs are removed ( $>99 \%$ ), but small HCP amounts remain in the distributed products, such as monoclonal antibodies (mAbs), antibody-drug-conjugates(ADCs), therapeutic proteins, vaccines, and other protein-based biopharmaceuticals.

Antibody-drug conjugates or ADCs are an important class of highly potent biopharmaceutical drugs. ADCs are a mixed complex of Anti-body and cytotoxic drug, which allows for discrimination between healthy and diseased cells, unlike chemotherapeutics. 
In Conclusion, we could say that our future is safe with such techniques, but our present is still vague. All the technology we have today, are not applicable due to their great cost; but science has not limit. We might be able to use it tomorrow on daily basis in every laboratory or hospital. What we are not sure about is the revelation and challenges, the biological system is holding for us. That's why we need to be one step ahead all the way.

\title{
ПРИМЕНЕНИЕ ИСКУССТВЕННЫХ НЕЙРОННЫХ СЕТЕЙ ДЛЯ ДИАГНОСТИКИ ЗАБОЛЕВАНИЙ СЕРДЦА
}

\author{
Гривков А.В. ${ }^{*}$, Смирнов А.А. \\ Уральский федеральный университет имени первого Президента России Б.Н. Ель- \\ цина, г. Екатеринбург, Россия \\ "E-mail: a.a.smirnov@urfu.ru
}

\section{APPLICATION OF ARTIFICIAL NEURAL NETWORKS FOR HEART DISEASES DIAGNOSTICS \\ Grivkov A.V. ${ }^{*}$, Smirnov A.A. \\ Ural Federal University, Yekaterinburg, Russia}

Annotation. The goal of the project is to design a program based on machine learning algorithms, performing analysis of a one-dimensional ECG signal and reporting a particular pathology.

Основной проблемой ЭКГ-метода диагностики сердечно-сосудистых заболеваний является то, что традиционные методы анализа достаточно часто обладают малой достоверностью. Некоторые серьезные заболевания сердца отражаются на ЭКГ лишь малозаметными изменениями амплитуды или формы пиков. В таких случаях точность диагноза зависит почти полностью от опыта и классификации врача. Для исключения «человеческого фактора» процесс необходимо автоматизировать и найти метод, способный распознавать любые характерные для определенного заболевания изменения. В данном проекте рассматривается вариант решения этой задачи с помощью использования искусственных нейронных сетей (ИНС) и алгоритмов машинного обучения.

Современные ИНС могут быть использованы в качестве средства прогнозирования во времени, средство распознавания образов, инструмент для поиска по ассоциациям, модель для поиска закономерностей в массивах данных.

Целью данного проекта будет создание ИНС, ее обучение с помощью находящихся в открытом доступе отечественных и зарубежных баз данных патологических и нормальных ЭКГ-сигналов, а также проектировка пользовательского интерфейса. Для написания программы будет использоваться язык 